DOI https://doi.org/10.36059/978-966-397-197-1/153-172

\title{
THE ART OF BOOK IN THE 17th-18th CENTURIES
}

\section{Karakoz Olena}

\section{INTRODUCTION}

Total digitization of all spheres of life of modern society leads to the transformation of social and cultural processes. Under the influence of digital technology, a new artistic space is being formed. In such conditions, art as a universal form of mirroring the man's inner beauty, which influences on the formation of the society's spiritual development and thus contributes to the humanistic orientation of all spheres of civilization, acquires special significance. In the process of its development, art enriches with new pieces of art, and each of them has a stamp of time.

There was a special cult of a book in ancient times. The publications were kept very carefully, treated as great value and even as a sacred object. Partly it can be explained that it took months to compose one book because each edition was done manually. The cost of materials, finishing and decoration of books was also of great importance - the books were made to be attractive, so they were often decorated with precious stones and metals, hand-paintings, etc. They always had a symbolic meaning. Respect for books in world culture cannot be overestimated. A book is a complex phenomenon of culture and art. $^{1}$ It was and still is a natural element of European civilization, one of the main specific features of this culture. ${ }^{2}$

A book has always being advanced simultaneously with society and embodied its main achievements; it was always a reflection of those events that took place in the social, cultural, political life during the historical development of human civilisation. On the other hand, the progressive development of society, its growing intellectual demands has

1 Karakoz O. O. (2019) Tradytsiina knyha - fenomen suchasnoho sotsiokulturnoho prostoru [The traditional book is a phenomenon of modern sociocultural space]. Library Science. Rekord Studies. Informology, no. 3, p. 95.

${ }^{2}$ Hrypych S. (2011) Knyha yak osnova rozvytku dukhovnoi ta intelektualnoi kultury liudyny [The book as a basis for the development of spiritual and intellectual culture man]. Bulletin of the Book Chamber, no. 9, pp. 1-3. 
improved the technology of book production and the organisation of its distribution. Each element of its decoration and finishing is a painstaking work of peoples for centuries. After all, such a wonderful acquisition of human culture, as a book, was created not immediately and not by virtue of some genius, but as a result of the long-lasting progress of entire nations, via the difficult way of survival and knowledge the essence of their own being. ${ }^{3}$

Precisely because of the centuries-long work by prominent artists the art of the book has emerged - a field of artistic activity aimed at creation of a book as an art visual form of expression of a work ${ }^{4}$ and one of the highest cultural achievements of humanity, the unity of spiritual and material culture. ${ }^{5}$ The masters of the book design, especially in the 17th-18th centuries, did a lot for the general exaltation of the fine arts and laid the basic traditions of the art of the book, which have been further developed in modern design and printing art.

The best works of book graphics became a valuable asset of the common treasure-house of European culture. The art of book design is intended not only to create an artistic image that should please the reader with its beautiful and attractive appearance, first of all, but it should also be a great and sincere friend, an assistant of a reader. The illustrations of the book, its font design, decoration, ornamental decorations everything that we call book graphics - actively help the reader to understand the literary work, its artistic images, enriches it ideologically. ${ }^{6}$

The modern world of digital technologies transforms gradually a printed book from a source of information to a work of art and an object of collectors' attention. The availability of information and the spread of electronic analogues of the book set new challenges not only for

\footnotetext{
${ }^{3}$ Karakoz O. O. (2018) Istoriia knyhy [History of the book]. Kyiv: Lira-K.

${ }^{4}$ Markova V. A. (2009) Mystetstvo knyhy: komunikatyvnyi aspekt [The art of the book: the communicative aspect]. Visnyk Kharkivskoi derzhavnoi akademii kultury, iss. 28, pp. 100-106.

${ }^{5}$ Halynska H. I. (2019) Rol khudozhnyka v knyzi dlia ditei [The role of the artist in a book for children]. Proceedings of the Khudozhnyk $i$ knyha (Ukraine, Kyiv, May 7, 2019) (eds. Chebykin A. V., Yakovliev M. I., Bitaiev V. A., Perevalskyi V. Ye., Fedoruk O. K., Berdynskykh S. O., Kharchenko P. V.), Kyiv: Natsionalna akademiia mystetstv Ukrainy, p. 7.

${ }^{6}$ Hapon Yu. Ya. (1967) Mystetstvo oformlennia knyhy - vazhlyvyi faktor estetychnoho vykhovannia [The art of book designin is a very important factor of the aesthetic education]. Printing and Publishing, no. 3, p. 147.
} 
publishers but also for the artists involved in the design of the printed products. In this context, various author's tools for the creation of art books are actively developed, among which the principle of synergy is implemented, as the interaction of different parts within the objets d'art.

\section{The Art of Book in the 17th Century: the Main Innovations and Changes in the Illustration Technique}

Belarusian first pressman Frantcysk Skaryna pointed to the communicative function of the art of book decoration, the use of which for a printed book is necessary for "better perception" by a reader. Although this activity is inherent to the book in one way or another since its emergence (the search for the most appropriate form for a particular culture), it received its theoretical foundations only in the 20th century. The outstanding master of illustration and the theorist of book art V.A. Favorsky considered that the art of book is synthetic art, the task of which, first of all, is in the spatial representation of the work, which moves in time, that is, in the organisation of the movement of the work in a certain rhythm. This was exactly what the book design should have been aimed at. V. Markova states: "The mentioned ideas are of great importance for understanding of the communicative nature of a book because each element of the book ensemble is perceived by V.A. Favorsky namely in the context of transferring of the text movement, which should be appropriately embodied in the rhythm of the book design: all elements of a book - a cover, a flyleaf, a title, separate pages, a headpiece, endings, illustrations - organise movement within it, as they mark the beginning and the end, as well as its partitioning in a certain way". The most consistent theory of the art of book as a means of communication in the 70s of the last century was developed by V.M. Liakhov. It is embodied in the model of the functional structure of a book, where a book is shown as a complex and multifaceted system based on the functional interaction of links of the elements taken in relation to the man - the consumer of the book. If traditionally the task of creation of a book ensemble was to combine three components: aesthetic,

${ }^{7}$ Lutsyshyna D. V. (2019) Pryntsypy synerhii u tvorenni ta prezentatsii art-knyhy khudozhnytseiu A. Komarovoiu [Principles of synergy in the creation and presentation of art books by artist A. Komarova]. Proceedings of the Khudozhnyk $i$ knyha (Ukraine, Kyiv, May 7, 2019) (eds. Chebykin A. V., Yakovliev M. I., Bitaiev V. A., Perevalskyi V. Ye., Fedoruk O. K., Berdynskykh S. O., Kharchenko P. V.), Kyiv: Natsionalna akademiia mystetstv Ukrainy, pp. 13-14. 
communicative and material and technical, then V.M Liakhov considered that the aesthetic nature of the book organism lies precisely in its communicativeness, i.e. the ability to convey the text message as much as possible. ${ }^{8}$

The new definition "book design" was introduced in the middle of the 20th century. In the monograph of the well-known Ukrainian researcher B. Valuienko The Book of Architecture, such components of a book were analysed as the design of the book block, variants of the combination of a strip of a set with illustrations, font typography, etc. V. Liakhov, $\mathrm{Yu}$. Herchuk and other art historians also studied this field. In the second half of the 20th century, the idea that the architectonics of a book is the basis of the coexistence of all its components asserts gradually, presents a book as a unique synthetic object that combines different types of arts: literature, fine arts and abstract sign systems (font and ornament). Touching the materials of the cover, the texture and the colour of the flyleaves are made of, the book block paper, the process of page-turning, compliance with the point types of composed fonts, technique of illustration execution, even the colour of the bead and bookmark in the artist's hands - the book masters work for the content, idea and literary style of the artist work. ${ }^{9}$

At the same time, as it is known, the highly professional use of different artistic languages in a single work - the combination of the creative intent of the text creator with the publication design by the artist, illustrator - increases greatly the artistic value of the printed edition. The task of all participants of the publishing process is a masterful combination of the form and content of the artistic image, the creation of such a holistic, bright, perfect and, at the same time, a modern printed edition, that will be able to interest the potential target audience - those

${ }^{8}$ Markova V. A. (2009) Mystetstvo knyhy: komunikatyvnyi aspekt [The art of the book: the communicative aspect]. Visnyk Kharkivskoi derzhavnoi akademii kultury, iss. 28, pp. 100-106.

${ }^{9}$ Mitchenko V. S. (2019) Pro maibutnie paperovoi knyhy [About the future of the paper book]. Proceedings of the Khudozhnyk $i$ knyha (Ukraine, Kyiv, May 7, 2019) (eds. Chebykin A. V., Yakovliev M. I., Bitaiev V. A., Perevalskyi V. Ye., Fedoruk O. K., Berdynskykh S. O., Kharchenko P. V.), Kyiv: Natsionalna akademiia mystetstv Ukrainy, pp. 15-16. 
who should buy it and get acquainted with the content getting positive aesthetic emotions in the process of perception of information material. ${ }^{10}$

The seventeenth century was characterised by intensification of the political struggle, activation of the democratisation of society, which required the publication of a large number of cheap editions. The $17^{\text {th }}$ century is characterised by significant cultural prosperity in Europe: universities, colleges, various schools are established in many cities, and the number of educated people rises significantly not only among the prosperous and middle classes of society but also among the common people.

Under these circumstances, the book began to be in demand. While the books were published mostly in Latin in the 15th and the first half of the 16th centuries, then the publications in the national languages English, French, German, Italian, Dutch, etc., prevail at the book market. And if in previous times the major percentage was for religious publications, aimed at a small number of educated readers, then in the 17th century the flow of political books, brochures and leaflets appeared and grew rapidly. The readers were provided with another, more popularized book. It was published in the national languages of different countries. One of the first works published in France in the national language, not Latin, was François Rabelais' book The Life of Gargantua and of Pantagruel. According to the contemporaries, it was sold out in a large number in two months. At this time, Shakespeare's books are published in England, Corneille's, Moliere's, and Racine's ones - in France, Lope de Vega's, and Calderon's books in Spain. The frolicsome novel replaces the knightly novel (the gallant novel is a genre of French and German literature of the mid-seventeenth century, which combines elements of knightly and Hellenistic novels. These novels use various materials, particularly taken from ancient historians). The novels of Cervantes, Scarron, Lesage, and Sorel were published in large numbers. The popularity of the genre was unbelievable. A five-volume novel by Madeleine de Scudery Clelia

${ }^{10}$ Kharchenko P. V. (2019) Novyi etap rozvytku syntezu mystetstv v oformlenni suchasnykh drukovanykh vydan [A new stage in the development of synthesis of the arts in the design of modern printed editions]. Proceedings of the Khudozhnyk $i$ knyha (Ukraine, Kyiv, May 7, 2019) (eds. Chebykin A. V., Yakovliev M. I., Bitaiev V. A., Perevalskyi V. Ye., Fedoruk O. K., Berdynskykh S. O., Kharchenko P. V.), Kyiv: Natsionalna akademiia mystetstv Ukrainy, pp. 31-32. 
(1662) might seem boring today, but at that time it was sold in huge circulation.

Complex relationships and struggle of social forces generate also a variety of artistic and ideological trends. Despite previous historical periods when art developed in the framework of homogeneous styles (Romanesque and Gothic), in the fine arts, together with traditional mythological and biblical genres, the secular one occupies the dominant place: domestic genre, landscape, portrait, and still-life paintings.

The 17 th century became a major factor in the formation of national cultures of Modern times. In this period, the process of localisation of large national schools, whose originality was determined both by the conditions of historical development and the artistic tradition in each country - Italy, Flanders, Holland, Spain, France - comes to an end. This allows us to consider the 17th century as a new stage in the history of the fine arts, characterised by the dominance of two great styles - baroque and classicism, elements of which are vividly expressed in book culture.

Both baroque and classicism are characterised by a desire for generalization, but the masters of the baroque tend to the dynamic masses, to complex unfolded ensembles and the features of these two great styles are often intertwined in the art of one country, and even in the work of the same artist, giving rise to contradictions in it. Along with baroque and classicism, in the fine arts, there is a more direct, more strong and realistic reflection of life, free from stylistic elements. The realistic direction is an important milestone in the evolution of Western European art. Its manifestations are extremely diverse and striking both in different national schools and in some masters of the book arts. ${ }^{12}$

At the same time, significant changes take place in the art and technique of illustration: the transition from xylograph (engraving on wood, where relief lines are printed over the form) to engraving on copper and letterpress. ${ }^{13}$

The printing technique became more complicated, and the technological integrity of a book, printed before along with illustrations and decorations from a single form, was violated. Now the illustrations

${ }^{11}$ Karakoz O. O. (2018) Istoriia knyhy [History of the book]. Kyiv: Lira-K, p. 265.

12 Yeroshkina O. O. (2017) Epokha baroko [The Baroque Era]. Kharkiv: O. M. Beketov Kharkiv National University of Urban Economics, p. 120.

${ }^{13}$ Karakoz O. O. (2018) Istoriia knyhy [History of the book]. Kyiv: Lira-K, p. 266. 
are printed separately (using another machine), usually on separate insert sheets, and place them between or after the pages of the text.

Meanwhile, this selection of graphics contributed partially to the architectonic clarity in the construction of the main text line. Now the placement of certain images in the text doesn't disturb its integrity, which was characteristic when printing xylography illustrations. The unified integrity and symmetrical structure of both the individual page and the uniformity of all pages as a whole became clearer in books. ${ }^{14}$

Developing the traditions of the Renaissance mainly, the artists of the 17th century expanded their interests and deepened the cognitive range of art greatly. Compared to the Renaissance, the Baroque era is more complex in its content and artistic forms. The integral poetic perception of the world, characteristic for the Renaissance, is destroyed; the ideals of harmony and clarity are unattainable. However, the image of a person remains invariably in the spotlight of artists. Its embodiment becomes more concrete, emotional and psychologically complex. ${ }^{15}$ The increase of interest in the individual personality, all features of his physical image and character, and special attention to the man's inner world have caused in many countries the incredible rise of portrait art, in particular the development of psychological portrait. ${ }^{16}$

The portraits of authors are begun to depict on the frontispieces of books that conveyed the textural and plastic variety, the elegance of Baroque painting. In the book of the 17th century, an engraved cover sheet preceded a typed one, depicting a complex spatial composition that conveyed the content of the book in an allegorical form. Its structure resembled a solemn altar or a triumphal arch, which allegedly opened the way to the space filled with various allegorical images. ${ }^{17}$ The copperengraved frontispieces, title pages and other graphic ornaments were filled with lush, three-dimensional shapes, made in the spirit of aesthetics

${ }^{14}$ Gerchuk Yu. Ya. (2000) Istoriya grafiki i iskusstva knigi [The history of graphics and book art]. Moscow: Aspekt Press, p. 192.

15 Yeroshkina O. O. (2017) Epokha baroko [The Baroque Era]. Kharkiv:

O. M. Beketov Kharkiv National University of Urban Economics, p. 120.

16 Yeroshkina O. O. (2017) Epokha baroko [The Baroque Era]. Kharkiv: O. M. Beketov Kharkiv National University of Urban Economics, p. 7.

17 Gerchuk Yu. Ya. (2000) Istoriya grafiki $i$ iskusstva knigi [The history of graphics and book art]. Moscow: Aspekt Press, p. 193. 
of the so-called Great Style. ${ }^{18}$ The famous artists made such compositions of titles. Thus, B. Moretus' publications, C. Plantin's successor, were designed by one of the most prominent painters of Flanders - Peter Paul Rubens. ${ }^{19}$ The characteristic feature of his work was the combination of realistic moments with mythological figures and allegories. $^{20}$

Changes happen in binding art too. In the 17th century, first France, and later other countries, became fascinated with dotted style (pointille) covers, which was started by the French bookbinder Le Gascon in 1620. His technique of decoration of leather covers was characterized by the fact that the ornamental and decorative motifs were composed not of thin lines, but of small dots, which formed thin lines. With the help of cover gilding technique, the masters made complex and at the same time delicate decorative patterns. The European countries borrowed quickly the means of cover decoration, started by Le Gascon: in the Netherlands, pointille was used in the design of Elsevier editions, which were "dressed" in green marocain; in England, dotted decorations were made in combination with stylized images of tulips and other flowers and plant forms. In the second half of the 17th century, various embossing stamps, made in the Le Gascon spirit, were sold at fairs in European countries. At this time, books were mostly printed in letterpress. It was distributed in the printing industry until new tools appeared. A huge number of publications were printed in letterpress - books, magazines, letterheads, illustrations etc. The exceptional versatility of this method is one of the positive factors; however, this method has a number of negative features, including the complicated production of the printing form, and the reproduction of these forms in the case of numerous replications. ${ }^{21}$

The Elseviers family became famous among the Dutch publishers, some of whom were merchants, and others were printers in different cities of the Netherlands and England. The Elsevier Company, founded by Lodewijk Elsevier, existed from 1581 to 1712 . The numeral dynasty

18 Ovchinnikov V. (2005) Istoriia knyhy: evoliutsiia knyzhkovoi struktury [History of the book: evolution of book structure]. Lviv: Svit, p. 313.

${ }^{19}$ Gerchuk Yu. Ya. (2000) Istoriya grafiki $i$ iskusstva knigi [The history of graphics and book art]. Moscow: Aspekt Press, p. 193.

${ }^{20}$ Yeroshkina O. O. (2017) Epokha baroko [The Baroque Era]. Kharkiv: O. M. Beketov Kharkiv National University of Urban Economics, p. 78.

${ }^{21}$ Karakoz O. O. (2018) Istoriia knyhy [History of the book]. Kyiv: Lira-K, p. 266. 
of Lodewijk (1540-1617), Matthijs (1564-1640), and Bonaventura (1583-1652), Abraham (1592-1652) was known in all European countries due to the publication of scientific and educational books.

Elseviers first published scientific literature in Latin, later began to publish books in the national languages - French, Dutch, Italian, German, as well as Arabic and other languages of the East. They often produced educational literature and fiction: the grammar of French, German, Hebraic, Arabic, Spanish and other languages. It was in their publishing house that the first Galileo Galilei's work The Discourses and Mathematical Demonstrations Relating to Two New Sciences (1638) was published. $^{22}$

The Elsevier famous series The Republics (The States), which was published in 1625-1640 in small volumes from year to year for decades, became especially famous. The Elseviers met the objective needs of the market - made a book much cheaper. The general reader was not interested in the external appearance of the publication, but above all its content, high scientific information value and affordable price of a book. To do this, they reduce the size of the book to $1 / 12$ of a piece of paper (approximately 135 $\mathrm{mm} \times 72 \mathrm{~mm}$ ), making it of a pocket-size, but, at the same time, do not reduce the text size of the publication. Small formats existed before the Elseviers, but the printers used large x-height fonts and their books were too thick. The Elseviers invited van Dyck, a well-known engraver and bookbinder from Antwerp, who made special fonts for the firm with small $(6,7,8$ points), but with a very clear face. These wonderful fonts have made Elzeviers very popular. A quality and simple font for the small format editions, developed in their printing houses, was called Elsevier; it is still used in our time. The Elseviers have produced several miniature editions that demonstrated clearly the publishers' achievements in printing and the art of book design. In 1627, a miniature book On the Royal Law was published. The following year, The Aphorisms of Hippocrates were published, the size of this book was reduced to $92 \times 44 \mathrm{~mm}$, and the format of The Satyricon by Petronius (1677) was $88 \times 48 \mathrm{~mm}$. All Elsevier printing houses have designed the books quite well. They used engraved illustrations, decorative covering of titles. The composite complex graphic frontispieces were engraved by leading masters. The Elseviers, like Plantins, did not save money on the decoration of books. The small volumes of the Elsevier Company with magnificently engraved frontispieces and output sheets

\footnotetext{
${ }^{22}$ Karakoz O. O. (2018) Istoriia knyhy [History of the book]. Kyiv: Lira-K, p. 267.
} 
depicting publishing stamps - a hermit under a tree, Minerva under a tree, an eagle with arrows, a palm tree, a sphere (globe) quickly got to all European countries. The Elsevier Company reached its greatest prosperity in the second half of the 17th century when it opened a book publishing office in Amsterdam and numerous representative offices in big European cities. ${ }^{23}$

The combination of high-quality design with professional editing and cost reduction has become the main feature of Elsevier editions.

The reduction of the book size led to a decrease in the price of books and increased circulation. At the same time, the books became affordable not only to the feudal lords, but also to ordinary people - their cheap book could be bought by students, teachers, and peasants. The Elseviers' activities became a real revolution in the book market because they make the book a universal commodity. At this time it becomes fashionable to carry books with you and for this purpose, a "book pocket" appears in clothing. Therefore, it is sometimes said that the Elseviers opened the pocketbook era. When the publisher Daniel Elsevier died, philosopher J. Locke said: "His death is a social loss". 24

The Royal, the first state printing house of France was founded in France, in the Louvre on the initiative of Cardinal Richelieu, in 1640, in which the checked corrected liturgical books were produced. This powerful printing house had a wealth of font equipment: great antique fonts, Greek fonts, and fonts of Eastern countries.

One of the features of its activities was the luxurious book design. The splendour and solemnity were reflected in the Baroque style, which prevailed in the French fine arts throughout the 17th and the early 18th centuries and reflected the noble and ecclesiastical culture of the period of imperial absolutism of the royal power ${ }^{25}$ and characterised by bright and expressive ornament, splendour, magnificence, combined with a wild emotionality and pathetic. ${ }^{26}$

The Royal Printing House published a 10-volume edition of the Bible with stunning illustrations. In magnificent editions, it usually glorified the absolutist power of the church and the king. The Royal Printing House published works of ancient classics with popular science commentaries for the heir to the French throne. The series consisted of

${ }^{23}$ Karakoz O. O. (2018) Istoriia knyhy [History of the book]. Kyiv: Lira-K, p. 268.

${ }^{24}$ Karakoz O. O. (2018) Istoriia knyhy [History of the book]. Kyiv: Lira-K, p. 269.

${ }^{25}$ Karakoz O. O. (2018) Istoriia knyhy [History of the book]. Kyiv: Lira-K, p. 269.

26 Yeroshkina O. O. (2017) Epokha baroko [The Baroque Era]. Kharkiv: O. M. Beketov Kharkiv National University of Urban Economics, p. 8. 
64 volumes in quarto format. The luxuriously decorated books were printed on high-quality paper with large point types. In 1692, Louis XIV commissioned the creation of a new font for the Royal Printing House. The commission of the Academy of Sciences under the guidance of the mathematician Nicholas Jenson developed the drawing of this font. ${ }^{27}$ The chief engraver of the Royal Printing House, Philippe Grandjean, without following the drawings of the commission, produced a font with a greater contrast of strokes than in the fonts of the old antiques created by N. Jenson and C. Garamond. This font was called "Royal Antiques". The bibliophile Duke de Grolier, Minister at Francis I, initiated the whole school of bookbinding, known as "Grolier". The Paris master was the first who began to put the author's name and title on the spine of a book. $^{28}$

Ph. Grandjean's font was the first modification of the Baroque antique, and, from a historical point of view, it can be characterized as a precursor of the transitional antique - the group of W. Caslon and J. Baskerville's fonts, which are even more contrasting.

The Baroque style prevailed in French art throughout the 17th and 18th centuries. ${ }^{29}$

\section{The Art of the Western European Book in the 18th Century}

At the beginning of the 18thcentury, the "aristocratic editions" dominated at the book market, frivolous sensuality and a passion for various beautiful and magnificent things prevailed in fashion. Such editions were designed in the Rococo style (the Rococo is a reversed Baroque style, which in the second half of the 18th century reached (from France and Austria) Ukraine - Kyiv, Lviv in the 1760-79s. The creative driving force of the Rococo era in all sections of culture was espri, as opposed to sensibilite of the Baroque or reason (raison) of classicism. Rococo style is created for the woman and adapted to her changing, at that time, tastes and whims. Almost the main word of the Rococo era was the word "whim". In art, it is defined by light, nervous, gentle and intricate forms (playful rococo).

${ }^{27}$ Karakoz O. O. (2018) Istoriia knyhy [History of the book]. Kyiv: Lira-K, p. 269.

${ }^{28}$ Karakoz O. O. (2018) Istoriia knyhy [History of the book]. Kyiv: Lira-K, p. 270.

29 Ovchinnikov V. (2005) Istoriia knyhy: evoliutsiia knyzhkovoi struktury [History of the book: evolution of book structure]. Lviv: Svit, p. 313. 
The luxury of the publication and the insane circulation made these books very expensive. A characteristic feature of "aristocratic editions" was Euphuism, a term that originated from the name of J. Lyly's novel, Euphues: The Anatomy of Wit, famous at that time. ${ }^{30}$ It is an artificial, precious, and full of metaphors and various literary expressions language that was quite common in the salons. The basis of this novel is the story of an aristocrat's adventures of the 16th century who invents his linguistic style (for example: “... the greenest beech burns faster than the driest oak; the purest silk decays faster of all; the sweetest wine quickly turns into the most acidic vinegar"). J. Lyly's new prose immediately provoked a flood of imitation. For a long time the Euphuism style, decorative and a bit fanciful, was fashionable among the representatives of the English aristocracy. However, the story was not lost in the centuries, and if, six years after the first edition, the novel Euphues: The Anatomy of Wit was reprinted five times more, then in the 20th century, J. Lilly could not complain about the inattention of publishers. The famous artists of the time, Francois Bouchet, Jean-Honore Fragonard, were invited to create the illustrations. The engraving on copper was created by Pierre-Philippe Chauffard, Noël Lemire, Philippe Le Bas and others. Many books with wonderful illustrations were republished: La Fontaine's Fables, Ovid's Metamorphoses. During the years 1761-1798, M. Voltaire's The Maid of Orleans endured 16 reeditions. The books that were fully engraved appeared: both text and drawings on copper plates. The French engravers and artists reached a high professional level in the second half of the 18th century: the small illustrations were decorated with carved scenes with the smallest details, demonstrating the marvels of the engravers' technical skills. ${ }^{31}$

The dramatic shifts occurred in book design. The book changed its appearance: its format became narrow and elongated. The characters in rows on narrow columns began to get denser, however, using large leadings and wide book margins. Leading French letter-founder Pierre Simon Fournier (1712-1768) created new varieties of antique fonts, beautiful italics and decorative initials, as well as new cast ornaments from which small vignettes, headpieces and various framing could be composed. The book texts in the Rococo style were accompanied by numerous illustrations of erotic content made in copper.

\footnotetext{
${ }^{30}$ Karakoz O. O. (2018) Istoriia knyhy [History of the book]. Kyiv: Lira-K, p. 312.

${ }^{31}$ Karakoz O. O. (2018) Istoriia knyhy [History of the book]. Kyiv: Lira-K, p. 313.
} 
Such literature was presented by the works of ancient Roman and Greek lyricists Anacreon, Sappho, Bion, Moschos, the books of erotic content by F. Rabelais, Moliere, J. La Fontaine and others. ${ }^{32}$

The most outstanding painters of the era participated in the illustrative design of the books $-\mathrm{F}$. Bouchet, H. Fragonard. ${ }^{33}$

The prosperity of illustrative art enriched and polished the technique of engraving on metal, bringing it to a special sophistication, a variety of shades, colour solutions. The attempts were made to multicolour print images. The xylography technique was used in the decorative book design, especially when making flower headpieces, endings and other coloured ornaments. ${ }^{34}$

The peculiarities of artistic decoration and design of the book page of the spread, the title and the strip changes from the 17th-18th centuries only in some details.

The role of type ornament was enhanced, the main characteristic of which was certain mobility and rhythm of forms. The page was clearly traced by depicting the dividing lines used to separate and highlight the opening lines and divide the text into chapters. They were usually decorated with a simple ornament. The decorative framings were used to illustrate and decorate the cover sheets. ${ }^{35}$

Along with the fashionable "aristocratic" editions, printed in small formats on high-quality paper with numerous illustrations on copper, the modestly decorated books of famous Enlighteners - famous figures of the Enlightenment era were very popular. The stories and dramas of Voltaire, Goethe, Rousseau's novels, Shakespeare's tragedies, and Beaumarchais's comedies were democratic. The design of the editions of these authors was not marked by certain splendour, characteristic for aristocratic editions. The classicism found its reflection in the noble simplicity of proportions - the style that corresponded to the canons of

\footnotetext{
${ }^{32}$ Karakoz O. O. (2018) Istoriia knyhy [History of the book]. Kyiv: Lira-K, p. 312.

${ }^{33}$ Gerchuk Yu. Ya. (2000) Istoriya grafiki $i$ iskusstva knigi [The history of graphics and book art]. Moscow: Aspekt Press, p. 199.

${ }^{34}$ Gerchuk Yu. Ya. (2000) Istoriya grafiki $i$ iskusstva knigi [The history of graphics and book art]. Moscow: Aspekt Press, p. 200.

${ }^{35}$ Gerchuk Yu. Ya. (2000) Istoriya grafiki i iskusstva knigi [The history of graphics and book art]. Moscow: Aspekt Press, p. 201.
} 
ancient art. The Enlighteners' books were more accessible and cheaper than aristocratic ones.

The art of book design reached the greatest flourishing in France in the 18th century. Among the 18th-century French figures, the Didot family was the most famous representatives in the field of book, paper and printing production. The founder of the company was François Didot (1689-1757), which opened the printing house and the bookstore in Paris in 1713. In the second half of the 18th century, the Didot company became the most powerful in Europe and produced products for many countries. The firm developed and cast printing fonts, printed books and magazines, owned numerous bookstores. One of the sons of the firms founders, François-Ambroise Didot, perfected the vellum paper invented by the English printer, J. Baskerville, by replacing some of the wooden parts with metal ones; together with his son Firmin Didot, he introduced and set clear rules for the printing system of measures and European type-foundry started to use it. Having used the font graphics of the famous Italian artist G. Bodoni, F.A. Didot created a wonderful antique font, which was called the Didot antique. Firmin Didot was the first who used the process of stereotypography in printing practice (making the exact copies of the printed type-setting forms, with the help of which later new solid printing forms for replication were cast), which reduced significantly the cost of the book production process and the cost of one copy. Pierre Didot, Firmin's brother, became famous as the publisher of the magnificent "Louvre Editions". Dido's beautifully designed books competed with the books of famous Italian book printer G. Bodoni.Even at the International Book Exhibition in 1806, the three-volume edition of the works by J.B. Racine, published by P. Didot, was recognized as the best edition of the century and a masterpiece of book printing art. ${ }^{37}$

At the end of the 18th - first quarter of the 19th century, a new style the Empire - began to form in France, England and other European countries, which was formed on the aesthetics of the classic monumental forms of the imperial Rome and ancient Greek archaic (the Empire style is a continuation of the revolutionary classicism and Neoclassicism in general). The empire was more solemn and pretentious. Ancient Rome remained a model for artists, but now it is no longer a republican one, but

${ }^{36}$ Karakoz O. O. (2018) Istoriia knyhy [History of the book]. Kyiv: Lira-K, p. 313.

${ }^{37}$ Karakoz O. O. (2018) Istoriia knyhy [History of the book]. Kyiv: Lira-K, p. 314. 
an imperial one with its palaces and triumphal arches. The Empire style is characterised by a tendency to strict grandeur and pomposity, cold elegance and the exaltation of the absolute power of military monarchies (the first empire in France, Russian Tsar Alexander I. Military emblems, weapons of ancient Rome, laurel wreaths, winged griffins, sphinxes, lions, etc. were used in the decorative ornamentation of the architectural structures, furniture, etc). P. Didot's books of this period have fonts with even greater contrast between the basic and auxiliary elements, and the drawing of the letters has become more geometric. The art decoration in P. Didot's books, starting with typeface, type-setting, the makeup of columns and ending with the production of graphic ornaments and copper-engraved illustrations, has acquired cold reasonableness, harshness and academicism. The book formats increased significantly during this period. The ornament of the binding covers was emphasized by the modesty: the thin gold linear frames in various combinations (one double or wavy line) were pressed along the binding edges: the mirror of the front binding cover remained mostly clear; sometimes in its central part the emblem or monogram of the customer, a decorative image of military emblems of imperial Rome or ancient Greek ornamental motifs were placed. The focus was on the decoration of the spine or even binding those divided its surface into parts and were considered as components of the overall composition of the spine. This style in the decoration of book covers is called Etruscan.

At the beginning of the 18th century, French bookbinders from the Padeloup family started a new artistic system of cover decoration with small stamps: a drawn thread style (dentelle), which became known in Western Europe. Afterwards, one of the representatives of this family Antoine-Michel Padeloup, the court binder of the French king, began to make famous mosaic leather covers, ornamented with decorative gilding with the help of small stamps.

In the era of Rococo art style development, French artists and amateurs create various magnificent book labels. In the mid-eighteenth century, monogram-type ex libris appeared in the form of interlaced first letters of the name and surname of the collection owner. Sometimes the monograms surrounded by a frame made in the spirit of the requirements of Rococo aesthetics or framed by decorative elements of the architectural plan. In the second half of the 18th century, the plot and decorative book labels appeared. The ex libris depicted the interiors of the customer's libraries. In the 18th century, the book labels were begun to collect. 
In the first half of the 18th century, the revival of the traditionally high artistic and printing level of the Italian book began, which was connected with the active work of Venetian printers, artists and engravers. The reforms in the field of book printing, which took place during the 18th century in many European countries, were supported by the prominent Italian publisher Giambattista Bodoni (1740-1813). It was he with whom the glory of the revival of the artistic traditions in the book art of Italy was connected. In 1791, G. Bodoni founded his own printing house at the royal palace. In both the Royal and his printing press, he paid much attention to the font culture both in the Royal and his own printing house. ${ }^{38}$

At first, G. Bodoni used the font and type-sitting ornament created by French bookmaker Pierre Simon Fournier and later began to make his own fonts. Based on the achievements of well-known masters of the font William Caslon, John Baskerville, François-Ambroise Didot and his son Firmin, as well as under the influence of the aesthetic views of the founder of the classicism German Johann Winckelmann and his famous work History of Ancient Art (1764) G. Bodoni developed and cast wonderful Latin, French, Greek, Cyrillic and other fonts. G. Bodoni adhered to the clear contrast between thin and thick lines in the construction of letters. His fonts were distinguished by sublimity and solemnity, but at the same time, they were characterised by a certain classic static character. At the end of the century, G. Bodoni's style took shape finally: he refused completely from the use of the decorative ornaments so that readers could enjoy the "simple beauty of the letters." He stressed that printmaking should show "what success it can achieve without the help of decoration."The books of G. Bodoni - the "master of simplicity" - were distinguished by quality, harmony and monumentality. G. Bodoni emphasised that the book perfection is determined by the beauty of the letters. After all, the beauty of the font is the basis on which the art of typography is based, because letters are the main material of the book, and everything else exists in the book due to them. In the preface to The Manual of Typography $(1788,1818)$, G. Bodoni said: "The letter will be wonderful when it will be more clearly seen in its orderliness, diligence, good taste and elegance. But in order it looks clear on the page, it is necessary to place it in a wellaligned line, not dense but not free (the ratio of the height of the line

${ }^{38}$ Karakoz O. O. (2018) Istoriia knyhy [History of the book]. Kyiv: Lira-K, p. 315. 
should be taken into account); moreover, each line one should leave the same intervals between the individual words, as between squadrons in the regiment, at which it would be impossible to insert any of the labels included in the alphabet".

G. Bodoni paid much attention in order his publications were distinguished by a high printing culture. He required printers to identify "blind" and dirty letters during the printing process so that the prints on the two adjacent pages did not appear as if they were printed on different machines. A printer was often occurred that the artistic and printing tasks were more important to him than literary ones and that his well-designed editions did not meet either scientific or literary requirements. For example, F. Didot wrote in the Parisian Encyclopaedic Magazine: "As a literary man I condemn his publication, as a printer - I admire them." During his lifetime, G. Bodoni produced more than a thousand books, among them such masterpieces of printing art as the collection of works by T. Tasso (1789), Horace (1791), Virgil (1793) and others. In 1806 he published the remarkable edition Oratio Dominica (Our Father), in which this prayer was presented in 155 languages. ${ }^{39}$

In the middle of the 18th century, John Baskerville, the book printer, became famous in England. He founded a printing house with a typefoundry and a paper mill in Birmingham in 1750. J. Baskerville began to cast fonts on his projects. He perfected the composition of black printing ink and was also the first among European printers who used vellum paper. In 1757, J. Baskerville published his first edition, the works of Virgil, with the help of new antique fonts on vellum paper, and in 1758, John Milton's Paradise Lost. J. Baskerville created a new style of book design that was marked by typographic rigidity: the artist refused almost completely from the use of illustrations and ornamental decorations, giving preference to the font design of the book. J. Baskerville's antique fonts have much greater contrast between the basic and auxiliary strokes in the construction of letters, so scientists classify them as transitional fonts. Based on the graphics of these fonts at the end of the 18th century, the fonts of the classical direction were developed, which had a greater contrast than J. Baskerville's ones. His new style in book design was developed by such famous book masters as F. Didot in France and G. Bodoni in Italy. ${ }^{40}$

\footnotetext{
${ }^{39}$ Karakoz O. O. (2018) Istoriia knyhy [History of the book]. Kyiv: Lira-K, p. 316.

${ }^{40}$ Karakoz O. O. (2018) Istoriia knyhy [History of the book]. Kyiv: Lira-K, p. 317.
} 


\section{CONCLUSIONS}

During its development, the art of book of the 17th - 18th centuries embodied the main achievements, acquisitions, artistic traditions of the culture of the Early Modern Period. The dominance of the two great styles - Baroque and Classicism, was reflected in the design, decoration, and book font culture. In the 17th and 18th centuries, transformational changes occurred in the art of book design, which had an impact on the further development and elevation of book culture.

The European binding art is characterised by changes in the means of decoration; new styles as pointille, dentelle and Etruscan were formed. A new, more sophisticated book appeared in beautifully decorated covers with leather-bound bindings with painted or gilt edges.

The important changes occurred in the features of the illustrations, and there were enhanced ornamental and decorative motifs, for the creation of which the most striking and fascinating artistic means were used. The book design was determined by the extraordinary luxury. The artists and engravers showed perfect technical skills in the illustrative design.

The font culture reached a high artistic level, new types of fonts were created, the characteristic features of which were sublimity, solemnity, and classic static character.

The wonderful italics, new initials, numerous copper illustrations, cast ornaments from which small vignettes could be composed of, headpieces, and various framings in Rococo and Empire styles made the book a true masterpiece. The most prominent artists of that time participated in the illustrative framing.

The art book culture of the 17th-18th centuries had its peculiarity and uniqueness and was determined by special beauty. The art of book of that time reflected the process of revival of the world art traditions. The work of the famous artists, painters, printmakers, who used new ways of art expression, were of great importance for the development of the art of book of this period.

The book of the 18th century became more sophisticated and was determined by the harmonious combination of all elements, acquiring a high artistic level. The traditions were established by the book masters during the researched period became the main factor for the development of the book arts promotion.

\section{SUMMARY}

A book is a work of art that synthesises the artistic word and main achievements of the fine arts of a particular historical era. All decoration 
elements, both inside and outside the book, create a complete work of art. The aim of the article is to study the peculiarities of the formation of the art of book in the 17th - 18th centuries, taking into account the achievements of the world fine arts. The scientific novelty is determined by the fact that the research expands and deepens knowledge about the basic principles of the development of the art of book from the point of view of comprehensive objectivity. Conclusions. During its development, the art of book of the 17th -18 th centuries embodied the main achievements, acquisitions, artistic traditions of the culture of the Early Modern Time. The dominance of the two great styles - Baroque and Classicism, was reflected in the design, decoration, and book font culture. In the 17th and 18th centuries, transformational changes occurred in the art of book design, which had an impact on the further development and elevation of book culture. The art book culture of the 17th-18th centuries had its peculiarity and uniqueness and was determined by special beauty. The art of book of that time reflected the process of revival of the world art traditions. The work of the famous artists, painters, printmakers, who used new ways of art expression, were of great importance for the development of book arts promotion.

\section{REFERENCES}

1. Gerchuk Yu. Ya. (2000) Istoriya grafiki $i$ iskusstva knigi [The history of graphics and book art]. Moscow: Aspekt Press. (in Russian)

2. Halynska H. I. (2019) Rol khudozhnyka v knyzi dlia ditei [The role of the artist in a book for children]. Proceedings of the Khudozhnyk $i$ knyha (Ukraine, Kyiv, May 7, 2019) (eds. Chebykin A. V., Yakovliev M. I., Bitaiev V. A., Perevalskyi V. Ye., Fedoruk O. K., Berdynskykh S. O., Kharchenko P. V.), Kyiv: Natsionalna akademiia mystetstv Ukrainy, p. 7.

3. Hapon Yu. Ya. (1967) Mystetstvo oformlennia knyhy - vazhlyvyi faktor estetychnoho vykhovannia [The art of book designin is a very important factor of the aesthetic education]. Printing and Publishing, no. 3, pp. 147-153.

4. Hrypych S. (2011) Knyha yak osnova rozvytku dukhovnoi ta intelektualnoi kultury liudyny [The book as a basis for the development of spiritual and intellectual culture man]. Bulletin of the Book Chamber, no. 9, pp. $1-3$.

5. Karakoz O. O. (2018) Istoriia knyhy [History of the book]. Kyiv: Lira-K. (in Ukrainian)

6. Karakoz O. O. (2019) Tradytsiina knyha - fenomen suchasnoho sotsiokulturnoho prostoru [The traditional book is a phenomenon of 
modern socio-cultural space]. Library Science. Rekord Studies. Informology, no. 3, pp. 93-101.

7. Kharchenko P. V. (2019) Novyi etap rozvytku syntezu mystetstv v oformlenni suchasnykh drukovanykh vydan [A new stage in the development of synthesis of the arts in the design of modern printed editions]. Proceedings of the Khudozhnyk i knyha (Ukraine, Kyiv, May 7, 2019) (eds. Chebykin A. V., Yakovliev M. I., Bitaiev V. A., Perevalskyi V. Ye., Fedoruk O. K., Berdynskykh S. O., Kharchenko P. V.), Kyiv: Natsionalna akademiia mystetstv Ukrainy, pp. 31-32.

8. Lutsyshyna D. V. (2019) Pryntsypy synerhii u tvorenni ta prezentatsii art-knyhy khudozhnytseiu A. Komarovoiu [Principles of synergy in the creation and presentation of art books by artist A. Komarova]. Proceedings of the Khudozhnyk $i$ knyha (Ukraine, Kyiv, May 7, 2019) (eds. Chebykin A. V., Yakovliev M. I., Bitaiev V. A., Perevalskyi V. Ye., Fedoruk O. K., Berdynskykh S. O., Kharchenko P. V.), Kyiv: Natsionalna akademiia mystetstv Ukrainy, pp. 13-14.

9. Markova V. A. (2009) Mystetstvo knyhy: komunikatyvnyi aspekt [The art of the book: the communicative aspect]. Visnyk Kharkivskoi derzhavnoi akademii kultury, iss. 28, pp. 100-106.

10. Mitchenko V. S. (2019) Pro maibutnie paperovoi knyhy [About the future of the paper book]. Proceedings of the Khudozhnyk $i$ knyha (Ukraine, Kyiv, May 7, 2019) (eds. Chebykin A. V., Yakovliev M. I., Bitaiev V. A., Perevalskyi V. Ye., Fedoruk O. K., Berdynskykh S. O., Kharchenko P. V.), Kyiv: Natsionalna akademiia mystetstv Ukrainy, pp. $15-16$.

11. Ovchinnikov V. (2005) Istoriia knyhy: evoliutsiia knyzhkovoi struktury [History of the book: evolution of book structure]. Lviv: Svit. (in Ukrainian)

12. Yeroshkina O. O. (2017) Epokha baroko [The Baroque Era]. Kharkiv: O. M. Beketov Kharkiv National University of Urban Economics. (in Ukrainian)

\section{Information about the author: Karakoz Olena, orcid.org/0000-0002-7772-1530} $\mathrm{PhD}$ in Historical Sciences, Associate Professor Kyiv National University of Culture and Arts 36, Yevhen Konovalets Str., Kyiv, 01133, Ukraine 